Original Research

\title{
Effectiveness of Slow Deep Breathing Exercise on Decreasing Stress Levels for Patients with Diabetes Mellitus
}

\author{
Warsono Warsono ${ }^{1}$, Arief Yanto ${ }^{1}$ \\ ${ }^{1}$ Universitas Muhammadiyah Semarang, Indonesia
}

\section{Article Info}

Article History:
Accepted May 7th, 2020

\section{Keywords:}

Slow deep breathing; Diabetes Mellitus; Stress Level

\section{INTRODUCTION}

Diabetes mellitus (DM) is a disease of metabolic disorder that occurs when the pancreas can not produce insulin with a marked presence of impaired metabolism of carbohydrates, proteins, and fats caused due to the increase in insulin levels in relative terms. Damage to the pancreas is due right of the swelling in the pancreas which is usually caused by digestive enzymes become active inside the pancreas, so that attack and destroy pancreatic tissue and causes diarrhea and even weight loss. ${ }^{1,2}$
Abstract

The prevalence of diabetes mellitus patients increases in Semarang province every year. Whereas, it reached 120 numbers of patients in Kedungmundu public health center by 2020. One of the psychological problems encountered by patients with diabetes is a high risk of stress levels. The condition of stress, anxiety, and fear influence the production of adrenaline hormones which aggravate the capability of patients to perform daily living activities. Slow deep breathing exercise is a nonpharmacologic method to reduce stress levels on diabetes mellitus patients. This study aimed to investigate the effect of slow deep breathing exercises on decreasing stress levels for patients with diabetes mellitus. This study used a quasiexperiment pretest-posttest with a control group design was conducted at Kedungmundu public health center, Semarang. All of 32 samples were recruited in this study. Wilcoxon test analysis calculated a value of $\mathrm{p}=0.000$ between the pretest and posttest in the experimental group. Slow deep breathing exercise is effective to decrease the stress levels for patients with diabetes mellitus. Slow deep breathing exercise is strongly suggested for patients with diabetes mellitus as self-intervention to reduce stress levels.
The level of prevalence globally patient DM in the year 2016 amounted to $11.3 \%$ of the total population of the world and experiencing an increase in the year 2017 into 677 million cases. Indonesia is a country that occupies the order of the 6th with patients DM number of 12.5 million people after China, India, United States, Brazil, Russia, and Mexico. Prevalence of DM by the data results in ${ }^{3}$ showed the prevalence of the disease is not contagious experience hike when compared with Riskesdas (2013) among others DM occurs an increase of $6.9 \%$ in the year 2013

Corresponding author:

Warsono

warsono@unimus.ac.id

South East Asia Nursing Research, Vol 2 No 2, June 2020

ISSN:2685-032X

DOI: https://doi.org/10.26714/seanr.2.2.2020.10-14 
increased into $8.5 \%$ in the year 2018 with the number of cases reaching 46,174 .

Stress is the body's reaction that occurs when a person is faced with a threat, pressure, or a change. Stress is also caused by environmental, economic, and unhealthy living factors, which are one of the triggers for diabetes mellitus. In times of stress, the pituitary gland in the brain decreases the production of the hormone serotonin. Serotonin is a mood-regulating hormone that affects the pancreas gland to secrete insulin. When stressed, the production of the hormone serotonin is produced in small amounts, insulin automatically decreases and can reduce its ability to neutralize blood sugar. because blood lacks insulin production, blood glucose will remain in the bloodstream without being able to enter the cell wall, so there is an increase in blood sugar. 4,5

Treatment diabetes or diabetes mellitus in general only be given treatment in the form of drug pharmacological such as metformin, and insulin therapy while nonpharmacological administration was not considered in nursing when one nurse handling to note that non-pharmacological therapy. Nonpharmacological therapy has not been widely applied by nurses in a hospital such as therapy in handling stress on diabetes mellitus. The method of slow deep breathing is one of the nursing actions that can reduce the stress that occurs a decrease in anxiety and automatically can lower blood sugar levels. Relaxation can influence the hypothalamus to regulate and decrease sympathetic nervous system activity. Stress can not only increase blood sugar levels physiologically. Patients in a state of stress can also change their good habit patterns, especially in terms of eating, exercise, and medication. ${ }^{6}$

The research entitled SDB (slow deep breathing) on anxiety levels and blood sugar levels in people with diabetes mellitus. Slow deep breathing research 2 times a week for 4 weeks, the results of the level of anxiety obtained by the p-value of the intervention group were $(0.000)<0.005$ and the results of the control group test obtained the $p$-value $(0.0830>0.05$, while on examination Blood glucose obtained by the $p$-value of the intervention group was decreased and the results of the control group test showed that the p-value was increased but not significant. ${ }^{7}$

Another research showed that the reduction in blood sugar levels was very significant in the intervention group after relaxing for seven days, and doing it twice a day. The highest decrease was on the seventh day $(p=0.000)$. Different sexes did not differ the mean reduction in KGD in the two groups $(p=0.730)$. And it can be concluded that relaxation can reduce blood sugar levels in type 2 DM patients. ${ }^{6}$

From patient data for the last 3 months, January-March 2019, it was found that there were 120 people with diabetes mellitus, both male and female, where respondents were still taking drugs such as metformin. Researchers aim to provide non-pharmacological therapy, namely slow deep breathing (SDB) therapy.

\section{METHODS}

This study used a quasi-experimental research design. The study design using pre-post-test control group design by using the instrument Hamilton Anxiety Rating Scale (HARS), which is done by providing a pre-test before treatment is given and do the re-measurement (post-test) after the treatment given to the intervention group while the control group did not give any therapy. Therapy or intervention is carried out after 7 hours to avoid the effect of the work of the drug that is consumed by the respondent. The sampling in this study by using a sampling probability technique random sampling with criteria inclusion of patients with diabetes mellitus for \pm 1 year, a patient who experiences anxiety with a score of 95-141 moderate stress, $p$ ria and women ages 30-50 35-55 years, suffering 
can communicate well and b willing to be a respondent. The population in the study were all people with diabetes mellitus at Kedungmundu Public Health Center Semarang, and data were obtained for the last 3 months from January to March 2019 with a total population of 120 people with diabetes mellitus at Kedungmundu Public Health Center Semarang area. The sample used in this study was 32 respondents consisting of an experimental group of 16 respondents and a control group without treatment of 16 respondents, this study was conducted on 22 September - 6 October 2019. Univariate and bivariate analysis data using the Wilcoxon test.

\section{RESULTS}

Characteristics and general description of respondents age, gender, last education of respondents, occupation of respondents, and stress level of respondents, which are presented in the central tendency in the form of frequency values. The number of respondents was 32 people $(n=32)$.

The results of the study have shown that the mean age of the respondents is in the late adulthood category. The mean age of the respondents was 43.19 years, with the youngest being 30 years old and the oldest being 55 years old.

Based on the Levene's statistics test, it is known that the stress experienced by respondents before the intervention has the same baseline $(p=0.104)$.

The effectiveness of the Slow Deep Breathing Exercise is known by comparing the stress values before and after the action.

The results of the study have shown that there is a significant difference between the average stress values before and after the intervention. whereas in the control group there were no similar results. So it can be concluded that slow deep breathing exercise intervention can reduce stress in diabetes mellitus patients.
Table 1

Characteristic

of respondents at Kedungmundu Public Health Center, Semarang $(n=32)$

\begin{tabular}{lcc}
\multicolumn{3}{c}{ Center, Semarang $(\mathrm{n}=32)$} \\
\hline Indicators & $\mathrm{f}$ & $(\%)$ \\
\hline Gender & & \\
Male & 15 & 46.9 \\
Women & 17 & 53.1 \\
\hline Occupation & & \\
$\quad$ Does not work & 15 & 46.9 \\
PNS / POLRI / TNI & 6 & 18.8 \\
Entrepreneur & 11 & 34.4 \\
\hline Education & & \\
Elementary school & 8 & 25.0 \\
Junior High & 9 & 28.1 \\
High school & 10 & 31.1 \\
Bachelor & 5 & 15.6 \\
\hline Level of stress & & \\
Mild stress & 9 & 28.1 \\
Moderate stress & 23 & 71.9 \\
\hline
\end{tabular}

Table 2

Differences in stress before and after the intervention

\begin{tabular}{lcc}
\hline \multicolumn{1}{c}{ Indicators } & $\begin{array}{c}\text { Intervention } \\
\text { group }\end{array}$ & $\begin{array}{c}\text { Control } \\
\text { group }\end{array}$ \\
\hline Stress score before & 71.88 & 126.69 \\
intervention & $( \pm 7,182)$ & $( \pm 3,772)$ \\
Stress score before & 69.06 & 129.50 \\
intervention & $( \pm 7,280)$ & $( \pm 4,719)$ \\
\hline & $0,0001^{*}$ & $0,425^{*}$ \\
\hline
\end{tabular}

* Wilcoxon test

\section{DISCUSSION}

In the adult age range related to behavior and lifestyle, a person tends to not pay attention to their food intake so that it can affect blood sugar levels and stress levels because the food content is not following diabetes mellitus suffered. ${ }^{8-10}$

Women have a higher risk of suffering neuropathic complications related to parity and pregnancy, large body mass index, and menstrual cycle syndrome as well as during menopause which results in inhibition of the transport of gnocchi into cells, leading to diabetes mellitus. ${ }^{11}$

The level of education is very influential in changes in attitudes and behavior in healthy living. Patients who have a low level of education will find it difficult to accept and understand the health messages conveyed 
so that it affects the patient's ability to respond to a problem he faces. Conversely, sufferers who have higher education will have broader knowledge also allow the patient to control himself in overcoming the problems at hand, have high selfconfidence, experience, and have the right estimate, how to deal with events, and easily understand what recommended by health workers in providing therapy. ${ }^{12}$

The level of employment of respondents as the motherhouse ladder includes sweeping, washing dishes, cooking including the activity of the physical light that has a risk of 4.36 times is great for people with diabetes mellitus in comparison with those that have activity moderate and severe. ${ }^{13,14}$

Levels of stress experienced by the response can be controlled by the treatment of slow deep breathing for therapy that is one of the independent nursing interventions that can be used to overcome the psychological symptoms of patients. It is important to teach patients to remember the conditions they face are uncertain, for example experiencing psychological symptoms. This relaxation can be useful for improving health conditions and inhibiting stress and anxiety. Because of the very strong connection between the body and the mind, it not only has a calming effect on the body but is also beneficial in giving calm to the mind. Until now, deep breathing relaxation is still one of the most widely used therapies because it is easy and does not require tools when performed. It only requires full concentration, a comfortable position, and can use imagination. 6,15,16

The results of these data indicate that the provision of slow deep breathing therapy reduces stress levels so that this study is proven.

\section{CONCLUSION}

Slow deep breathing exercise intervention can reduce the stress of diabetes mellitus patients. nurses can use this therapy to reduce stress in diabetes mellitus patients, to reduce the impact caused by stress.

\section{ACKNOWLEDGMENTS}

We would like to express our appreciation to all patients who participated in this research.

\section{CONFLICTS OF INTEREST}

Neither of the authors has any conflicts of interest that would bias the findings presented here.

\section{REFERENCES}

1. Haq T, Ahmed T, Latif ZA, Sayeed MA, Ashrafuzzaman SM. Cardiac autonomic neuropathy in patients with type 2 diabetes mellitus having peripheral neuropathy: A cross-sectional study. Diabetes Metab Syndr Clin Res Rev. 2019 Mar;13(2):1523-8.

2. Schvarcz E, Palmer M, Aman J, Horowitz M, Stridsberg M, Berne C. Physiological hyperglycemia slows gastric emptying in normal subjects and patients with insulindependent diabetes mellitus. Gastroenterology. 1997 Jul;113(1):60-6.

3. Kesehatan K, Penelitian B, Kesehatan P. Hasil Utama Riskesdas 2018. 2018.

4. Hegde S V., Adhikari P, Subbalakshmi NK, Nandini M, Rao GM, D'Souza V. Diaphragmatic breathing exercise as a therapeutic intervention for control of oxidative stress in type 2 diabetes mellitus. Complement Ther Clin Pract. 2012 Aug;18(3):151-3.

5. Fiskin G, Sahin NH. Effect of diaphragmatic breathing exercise on psychological parameters in gestational diabetes: A randomised controlled trial. Eur J Integr Med. 2018 Oct;23:50-6.

6. Chaddha A, Modaff D, Hooper-Lane C, Feldstein DA. Device and non-device-guided slow breathing to reduce blood pressure: A systematic review and meta-analysis. Vol. 45, Complementary Therapies in Medicine. Churchill Livingstone; 2019. p. 179-84.

7. Noble KA. The stressed patient with diabetes mellitus. J Perianesthesia Nurs. 2005 Oct;20(5):354-60.

8. Rochmawati DH. Makna kehidupan klien dengan diabetes melitus kronis, di Kelurahan 
Bandarharjo Semarang sebuah studi fenomenologi. 2013.

9. Noorratri ED. Peningkatan Kualitas Hidup Pasien Diabetes Mellitus Dengan Terapi Fisik. J Ilmu Keperawatan Komunitas. 2019 May;2(1):19.

10. Anissa M, Amelia R, Dewi NP. Gambaran Tingkat Depresi pada Lansia di Wilayah Kerja Puskesmas Guguak Kabupaten 50 Kota Payakumbuh. Heal Med J. 2019 Aug;1(2):126.

11. PH L, Sari IP, Hermanto H. Gambaran Tingkat Stres Pasien Diabetes Mellitus. J Perawat Indones. 2018 May;2(1):41.

12. Brunetti L, Kalabalik J. Management of type2 diabetes mellitus in adults: Focus on individualizing non-insulin therapies. $\mathrm{P} T$. 2012 Dec;37(12):687-96.
13. Im HJ, Kim YJ, Kim HG, Kim HS, Son CG. Kouksundo, a traditional Korean mind-body practice, regulates oxidative stress profiles and stress hormones. Physiol Behav. 2015 Mar;141:9-16.

14. Bhati $\mathrm{P}$, Hussain ME. Sleep duration is a significant predictor of cardiac autonomic neuropathy in type 2 diabetes mellitus. Prim Care Diabetes. 2019 0ct;13(5):452-61.

15. Jones CU, Sangthong B, Pachirat O. An inspiratory load enhances the antihypertensive effects of home-based training with slow deep breathing: A randomised trial. J Physiother. 2010 Jan;56(3):179-86.

16. Cant $\mathrm{S}$, Watts $\mathrm{P}$, Ruston $\mathrm{A}$. The rise and fall of complementary medicine in National Health Service hospitals in England. Complement Ther Clin Pract. 2012 Aug;18(3):135-9. 